\title{
IMPLEMENTASI EKSTRASI FITUR DAN K-NEAREST NEIGHTBOR UNTUK IDENTIFIKASI WAJAH PERSONAL
}

\author{
Danar Putra Pamungkas', Ahmad Bagus Setiawan ${ }^{2}$ \\ Teknik Informatika, Universitas Nusantara PGRI Kediri \\ Jl. KH. Achmad Dahlan Gg. 1 Mooroto Kota Kediri \\ E-mail:danar@unpkediri.ac.id, ahmadbagus@unpkediri.ac.id
}

\begin{abstract}
Abstraks
Wajah atau muka adalah bagian depan kepala pada manusia meliputi wilayah dari dahi hingga dagu, termasuk rambut, dahi, alis, mata, hidung, pipi, mulut, bibir, gigi, kulit, dan dagu. Sebuah sistem biometrika berdasarkan wajah diharapkan dapat menutup kelemahan sistem presensi konvensional yang berdasarkan tanda tangan. Beberapa kelemahan sistem tersebut antara lain, adanya celah kecurangan dalam proses tanda tangan dan waktu perekapan yang cukup lama. Penulis menggunakan metode ektraksi fitur Eigenface PCA sedangkan untuk klasifikasi menggunakan K-Nearest Neighbor. Akurasi pengenalan wajah dengan menggunakan metode ektrasi fitur eigenface dan K-NN mencapai $80 \%$. Nilai rata-rata FAR terendah adalah 20\% sedangkan FRR $15 \%$. Semakin banyak data latih yang digunakan akurasinya semakin tinggi. Akurasi optimal didapat pada kondisi jarak $50 \mathrm{~cm}$ dengan cahaya terang.
\end{abstract}

Kata Kunci: wajah, ekstrasi, fitur, $K-N N$

\section{PENDAHULUAN}

Ciri khas personal yang melekat pada tubuh seseorang antara lain sidik jari, wajah, tangan, kaki, dan retina. Wajah atau muka adalah bagian depan kepala pada manusia meliputi wilayah dari dahi hingga dagu, termasuk rambut, dahi, alis, mata, hidung, pipi, mulut, bibir, gigi, kulit, dan dagu (KBBI, 2008). Elemen-elemen itulah yang membuat wajah manusia memiliki bentuk yang berbeda-beda sehingga wajah sering digunakan sebagai identitas suatu individu dengan individu yang lain. Teknologi pengenalan diri dengan menggunakan bagian tubuh atau perilaku manusia disebut dengan sistem biometrika (Putra, 2009).

Sebuah sistem biometrika berdasarkan wajah diharapkan dapat menutup kelemahan sistem presensi konvensional yang berdasarkan tanda tangan. Beberapa kelemahan sistem tersebut antara lain, adanya celah kecurangan dalam proses tanda tangan dan waktu perekapan yang cukup lama. Penulis akan menggunakan ciri wajah personal untuk digunakan dalam sistem presensi. Sistem biometrika yang akan dibuat membutuhkan data wajah personal. Data wajah tersebut merupakan data masukan pada sistem yang berupa data citra. Citra adalah gambar pada dua dimensi (Aditya, 2013). Sistem yang menggunakan data masukan citra merupakan salah satu pengolahan citra. Pengolahan citra merupakan suatu proses yang dilakukan dengan masukan berupa citra dan hasilnya juga berupa citra (Efendy,2009).

Sistem pengenalan wajah membutuhkan sebuah ciri dari suatu citra untuk dapat dikenali kemudian ciri tersebut akan dicocokan dengan ciri citra lain. proses tersebut membutuhkan suatu metode ektraksi ciri atau fitur dan klasifikasi. Metode ektraksi fitur dan jumlah neighbor yang melakukan voting mempengaruhi tingkat akurasi klasifikasi gambar (Fuad,2017). Proses pengenalan wajah dapat berbeda dari data objek yang digunakan (Wang,2017). Sistem biometrika untuk pengenalan wajah memiliki tingkat akurasi $87 \%$ dengan menggunakan klasifikasi jaringan syaraf tiruan sedangkan dengan klasifikasi euclidean distance memiliki akurasi $68.45 \%$ (Fitriyah, 2015). Selain metode Klasifikasi Jaringan Saraf Tiruan metode Principal Component Analysis (PCA) juga dapat digunakan untuk pengenalan wajah. Eigenface merupakan salah satu metode pengenalan wajah berdasarkan Principal Component Analysis (PCA) yang mudah diimplementasikan (Fatta, 2009). Pengenalan wajah menggunakan metode PCA dengan menggunakan data sebanyak 130 gambar memiliki tingkat akurasi 82,27\% (Salamun, 2016). Deteksi wajah dengan menggunakan metode eigenface dapat memberikan tingkat kemiripan dengan nilai prosentase $80 \%$ (Putra, 2013). Metode Eigenface dan City Block Distence dapat mengenali wajah dengan rata-rata akurasi $69,86 \%$ (Pamungkas,2017). Akurasi identifikasi citra dengan metode klasifikasi K-Nearest Neighbor mencapai 88,9\% (Wulanningrum,2018).

Penulis menggunakan metode ektraksi fitur Eigenface PCA sedangkan untuk klasifikasi menggunakan K-Nearest Neighbor. Citra yang digunakan berformat jpg dan bmp. Resolusi citra tes adalah 640x480 pixel. Deteksi wajah menggunakan Webcam 0,3 MP. Data citra sempel diambil dua kali dari 10 orang mahasiswa lingkup UN PGRI Kediri.

\subsection{Pengenalan Pola}

Pengenalan Pola atau Pattern Recognition dalah suatu proses atau rangkaian yang bertujuan mengklasifikasikan data numerik dan symbol. Banyak teknik statistik dan sintksis yang telah dikembangkan untuk keperluan klasifikasi pola dan teknik-teknik ini dapat memainkan peran yang penting dalam system visual ntuk pengenalan obyek 
yang biasanya mmerlukan banyak teknik. Bentukbentuk obyek tertentu dalam dunia nyata yang sangat kompleks dapat dibandingkan dengan polapola dasar di dalam citra sehingga penggolongan obyek yang bersangkutan dapat dilakukan dengan lebih mudah (Ahmad, 2009).

Sistem Pengenalan pola dasar terdiri dari (Fatta, 2009):

\section{a. Sensor}

Sersor digunakan untuk menangkap objek yang cri atau fiturnya akan dieksraksi.

b. Mekanisme Pre-Processing

Mekanisme pengolahan objek yang ditangkap oleh sensor biasanya digunakan untuk mengurangi kompleksitas ciri yang akan dipakai untuk proses klasifikasi.

c. Mekanisme Pencari Fitu(manual/otomatis) Bagian ini digunakan untuk mengekstraksi ciri yang telah melalui tahap preprocessing untuk memisahkannya dari fitur-fitur pada objek yang tidak diperlukan dalam proses klasifikasi.

d. Algoritma Pemilah

Pada tahapan ini proses klasifikasi dilakukan dengan mengunakan algoritma klasifikasi tertentu. Hasil dari tahapan ini adalah klasifikasi dari objek yang ditangkap ke dalam kriteria-kriteria yang telah ditentukan.

\subsection{Pengenalan Wajah}

Pengenalan wajah merupakan salah satu pendekatan pengenalan pola untuk keperluan identifikasi personal disamping pendekatan biometrik lainnya seperti pengenalan sidik jari, tanda tangan, pengenalan citra wajah berhubungan dengan obyek yang tidak pernah sama, karena adanya bagian-bagian yang dapat berubah (Putra, 2013).

\subsection{Eigenface}

Salah satu metode untuk ekstraksi fitur adalah Eigenface. Eigenface salah satu algoritma pengenalan wajah yang didasarkan pada Principle Component Analysis (PCA) yang dikembangkaan di MIT. Algoritma eigenface pada training image dipresentasikan dalam sebuah vector flat (gabungan vector) dan digabung bersama-sama menjadi sebuah matriks tunggal. Eigenfaces dari masing-masing citra kemudian diekstraksi dan disimpan dalam file temporary atau database. Test image yang masuk didefinisikan juga nilai eigenfaces-nya dan dibandingkan dengan eigenfaces dari image dalam database atau file temporary. Adapun algoritma selengkapnya adalah :

1. Buat Make Flat Vektors(ImageList, $N, M$ ): ImageList adalah kumpulan dari $N$ training image, di mana setiap image adalah $W \times H$ piksel, $M$ adalah ukuran vector flat yang harus dibuat.

2. Gabungkan setiap image dalam $W H$ elemen vector dengan menggabungkansemua baris. Buat ImageMatrix sebagai matriks $N x W H$ berisi semua gambar yang digabung.

$$
\left[\begin{array}{lll}
a & b & c \\
x & y & z
\end{array}\right] \rightarrow\left[\begin{array}{llllll}
a & b & c & x & y & z
\end{array}\right]
$$

3. Jumlahkan semua baris pada ImageMatrix dan bagi dengan $N$ untuk mendapatkan rataan gambar gabungan. Kita namakan vector elemen $W H$ ini dengan $R$.

4. Kurangi ImageMatrix dengan everage image $R$. Kita namakan matriks baru ukuran $N x W H$ sebagai $R^{\prime}$.

5. Jika pada elemen-elemen dari matriks $\mathrm{R}^{\prime}$ ditemuka nilai negative ganti nilainya dengan 0 .

Kemudian identifikasi dilakukan dengan proyeksi menggunakan algoritma seperti berikut :

1. Buat projectToFaceSpace (test_image): image berukuran $W x H$ piksel.

2. Kita gabung elemen vector $W H$ dan kita sebut img.

3. Load nilai rataan $R$ dari database atau file.

4. Kurangi img dengan $R$ sehingga kita dapatkan img'.

5. Jika pada img' ditemukan elemen dengan nilai negative, ganti dengan nilai 0 untuk mendapatkan vector ukuran img'.

Proses terahir adalah identifikasi, yaitu memproyeksikan test image ke face space dan menghitung score.

1. Load semua wajah yang sudah diproyeksikan dari database.

2. Proj=projectToFaceSpace(test_image).

3. Lakukan operasi pengurangan, proj dengan semua wajah yang telah diproyeksikan. Ambil nilai absolutnya da jumlahkan, hasilnya adalah score.

Ambil score terkecil sebagai hasil dari wajah yang telah diproyeksikan. Wajah ini menjadi identifikasi (Fatta, 2009)

\subsection{K-Nearest Neighbor}

K-Nearest Neigbor adalah algoritma supervised learing dimana hasil instance yang baru diklasifikasikan berdasarkan mayoritas dari katogrodi K-tetangga terdekat. Metode Manhattan Distance merupakan salah satu dari metode KNearest Neighbor. Manhattan Distance digunakan untuk menentukan kesamaan antara dua buah objek. Hasil pengukuran didasarkan penjumlahan jarak selisih antara dua objek. Hasil dari Manhattan Distance bernilai mutlak (Sinwar,2014). Berikut adalah persamaannya:

$$
d_{i j}=\sum_{k=1}^{n}\left|x_{i k}-x_{j k}\right|
$$




\section{PEMBAHASAN}

\subsection{Metodologi Penelitian}

Langkah-langkah yang ditempuh dalam penelitian ini dapat dilihat pada gambar 1 .

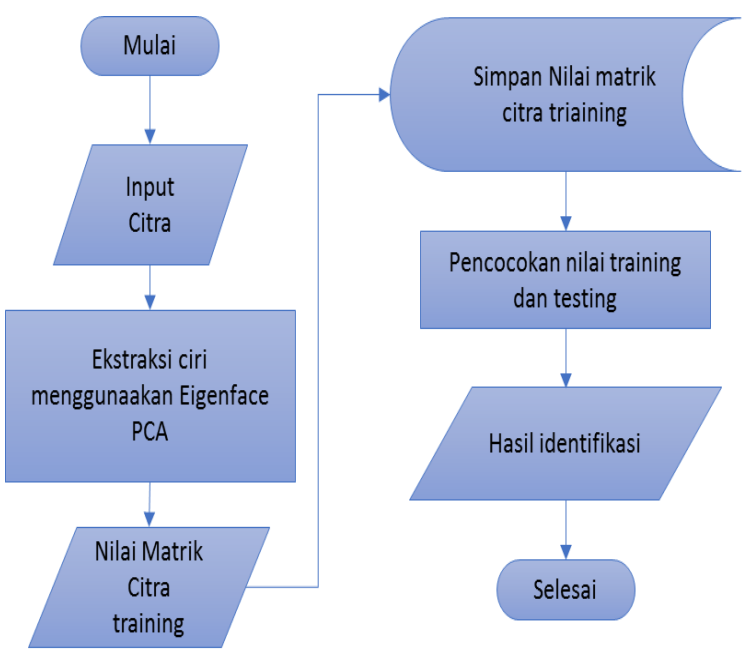

Gambar 1. Alur Penelitian

Input Citra

Pada tahap ini citra hasil capture dari webcam dimasukan untuk dijadikan citra training atau pelatihan. Citra pelatihan diambil dua kali dari 10 orang mahasiswa.

\section{Ekstraksi Ciri Menggunakan Eigenface PCA}

Pada tahap ini merupakan mencari ciri dari citra yang digunakan. Data nilai ciri tersebut akan dijadikan data latih atau training. Data tersebut berupa nilai matrik citra.

\section{Pencocokan Nilai Training dan Testing}

Pada tahap ini adalah proses pencocokan antara data latih dan data tes. Proses pencocokan ini menggunakan metode Manhattan Distance.

\subsection{Top Down Implementasi Sistem}

Tahap implementasi pada deteksi wajah menggunakan metode eigenface PCA sesuai dengan alur implementasi top-down. Model top-down ini merupakan model yang sering digunakan pada pembuatan sistem karena pengerjaan aplikasi secara berurutan linier. Berikut ini urutan dalam pengerjaan program sebagai berikut :

a. Buka Webcame

Webcame harus di aktifkan untuk menjalankan fungsi pendeteksi wajah atau untuk menampilkan gambar yang ditangkap webcame kedalam aplikasi.

b. Capture image

Penangkapan citra wajah (image capturing) dapat dilakukan secara langsung (real-time) menggunakan webcame, setelah terdeteksi adanya gambar wajah pada tampilan window dari webcame. c. Pemrosesan Awal

Proses pemrosesan awal meliputi normalisasi ukuran citra, RGB ke grayscale, histogram equalization untuk memperbaiki kualitas citra input agar memudahkan proses pengenalan tanpa menghilangkan informasi utamanya.

d. Hitung nilai Eigenface

Proses menghitung nilai eigenface yang menghasilkan nilai eigenvalue dan eigenvector.

e. Identifikasi

Proses pengenalan wajah dengan menghitung jarak antara fitur wajah yang ada dalam data dan fitur wajah yang baru. Jarak yang didapat dicari yang terkecil untuk identifikasi

\subsection{Debuging}

Debugging merupakan tahap untuk meningkatkan kinerja sistem dengan mencari dan mengurangi kesalahan atau kerusakan di dalam sistem yang telah diimplementasikan. Dengan proses debugging, dapat diketahui apakah perangkat telah bekerja sesuai dengan kebutuhan. Pada proses pembuatan sistem deteksi wajah untuk presensi terdapat proses debugging, antara lain adalah debugging data dan debungging coding.

a. Debugging Data

Debugging atau analisa data digunakan untuk mencari kesalahan pada data sample atau data training. Kesalahan yang mungkin terdapat pada data training adalah orientasi pengambilan data wajah yang tidak sesuai aturan seperti gelap terang ruangan atau posisi wajah yang setengah. Meskipun tidak mempengaruhi peforma dari sistem, namun ketidak konsistenan dalam hal orientasi maupun ukuran citra dapat menyebabkan kesalahan ekstraksi nilai.

b. Debugging Coding

Debugging coding dilakukan untk mencari kesalahan pada coding sistem yang menyebabkan sistem tidak dapatberjalan atau sistem berjalan namun memberikan hasil yang tidak tepat. Proses debuggingcoding dilakukan seiring dengan proses coding. Cara melakukan debugging coding adalah dengan menjalankan setiap fungsi coding dari sistem. Jika fungsi tidak bisa dijalankan, berarti ada kesalahan syntax coding yang harus diperbaiki. Jika fungsi bisa dijalankan, maka tetap harus dilakukan pengecekan antara output dari fungsi hasil coding dengan data asli.

\subsection{Perangkat Uji Coba}

Perangkat uji coba yang digunakan meliputi perangkat keras dan perangkat lunak. Spesifikasi perangkat keras dan lunak dapat dilihat pada tabel 1 . 
Tabel 1. Spesifikasi Perangkat Uji Coba

\begin{tabular}{|l|c|}
\hline Perangkat Keras & Perangkat Lunak \\
\hline 1. Prosessor : Intel Core & 1. Sistem Operasi \\
i3-6100U CPU @ & $:$ Windows 10 \\
2.30 GHz & pro 64-bit \\
2. Memory : Ram 6 GB & 2. IDE : Visual \\
$\begin{array}{l}\text { 3. webcam : 0,3 MP } \\
\text { 4. Harddiks : SSD }\end{array}$ & Studio 2013 \\
240GB & \\
\hline
\end{tabular}

\subsection{Skenario Uji Coba}

Uji coba dilakukan untuk mengetahui nilai akurasi, FAR (False Acceptance Rate) dan FRR (False Rejection Rate) dalam satuan persen (\%). Untuk mengetahui nilai-nilai tersebut ada tiga kondisi pengujian yaitu jumlah data latih, kondisi cahaya, jarak antara webcam dengan wajah. Kondisi cahaya redup menggunakan dua lampu neon sedangkan cahaya terang menggunakan 4 lampu neon. Uji coba dilakukan di salah satu ruang perkuliahan UN PGRI Kediri Ada empat skenario berdasarkan jumlah data latih. Skenario dapat dilihat pada tabel 2, 3,4 dan 5 .

Tabel 2. Skenario 1

\begin{tabular}{|c|c|c|}
\hline data training & kondisi cahaya & jarak $(\mathrm{cm})$ \\
\hline 3 & Terang & 50 \\
\hline 3 & Terang & 100 \\
\hline 3 & Redup & 50 \\
\hline 3 & Redup & 100 \\
\hline
\end{tabular}

Tabel 3. Skenario 2

\begin{tabular}{|c|c|c|}
\hline data training & kondisi cahaya & jarak $(\mathrm{cm})$ \\
\hline 5 & Terang & 50 \\
\hline 5 & Terang & 100 \\
\hline 5 & Redup & 50 \\
\hline 5 & Redup & 100 \\
\hline
\end{tabular}

Tabel 4. Skenario 3

\begin{tabular}{|c|c|c|}
\hline data training & kondisi cahaya & jarak $(\mathrm{cm})$ \\
\hline 8 & Terang & 50 \\
\hline 8 & Terang & 100 \\
\hline 8 & Redup & 50 \\
\hline 8 & Redup & 100 \\
\hline
\end{tabular}

Tabel 5. Skenario 4

\begin{tabular}{|c|c|c|}
\hline data training & kondisi cahaya & jarak $(\mathrm{cm})$ \\
\hline 10 & Terang & 50 \\
\hline 10 & Terang & 100 \\
\hline 10 & Redup & 50 \\
\hline 10 & Redup & 100 \\
\hline
\end{tabular}

\subsection{Hasil Uji Coba}

Dari empat skenario uji coba, setiap proses uji coba terdapat 5 mahasiswa sebagai data uji.

Hasil uji coba skenario 1 dengan menggunakan data latih 3 setiap citra mahasiswa dapat dilihat pada tabel 6.

Tabel 5. Hasil Uji Coba Skenario 1

\begin{tabular}{|c|c|c|c|c|}
\hline $\begin{array}{l}\text { kondisi } \\
\text { cahaya }\end{array}$ & $\begin{array}{l}\text { jarak } \\
(\mathrm{cm})\end{array}$ & $\begin{array}{l}\text { akurasi } \\
(\%)\end{array}$ & $\begin{array}{l}\text { FAR } \\
(\%)\end{array}$ & $\begin{array}{l}\text { FRR } \\
(\%)\end{array}$ \\
\hline Terang & 50 & 60 & 40 & 0 \\
\hline Terang & 100 & 40 & 20 & 40 \\
\hline Redup & 50 & 20 & 60 & 20 \\
\hline Redup & 100 & 0 & 60 & 40 \\
\hline
\end{tabular}

Dari tabel 5 dapat diketahui bahwa akurasi tertinggi adalah $60 \%$ pada kondisi cahaya terang dan jarak $50 \mathrm{~cm}$. Akurasi terendah pada kondisi redup dengan jarak $100 \mathrm{~cm}$ yaitu $0 \%$. Perbandingan akurasi dapat dilihat pada gambar 2 .

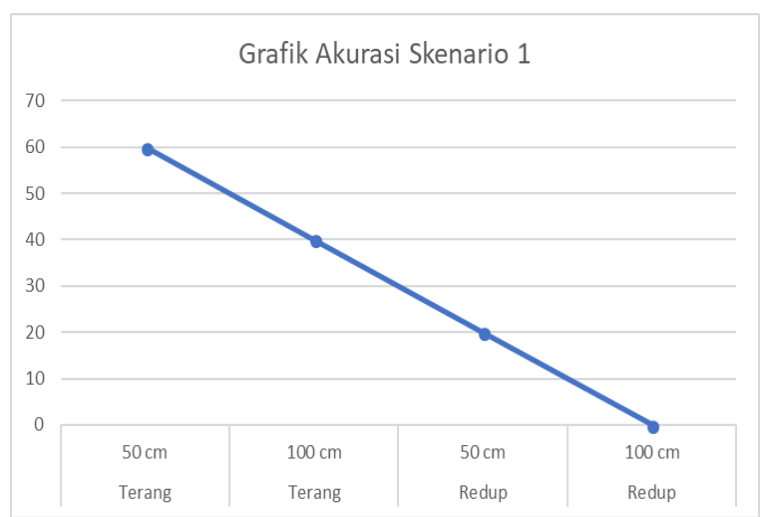

Gambar 2. Grafik Akurasi Skenario 1

Pada gambar 2 akurasi skenario 1 turun drastis dari kondisi terang dengan jarak $50 \mathrm{~cm}$ sampai dengan jarak $100 \mathrm{~cm}$ dengan keadaan redup.

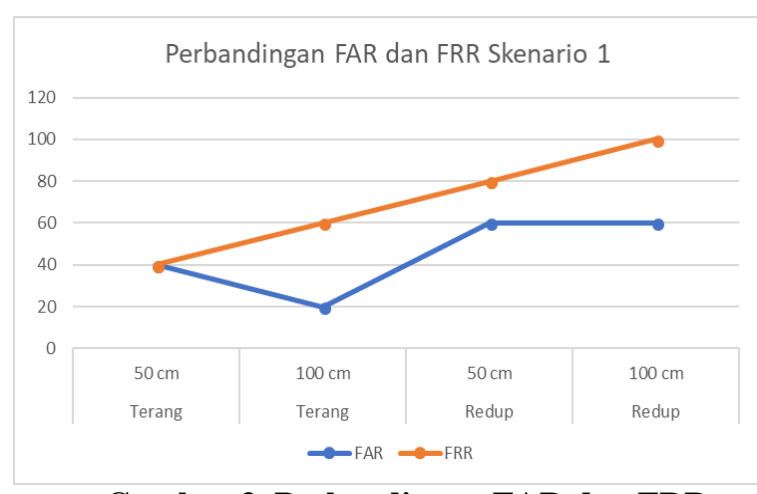

Gambar 3. Perbandingan FAR dan FRR Skenario 1

Perbandingan nilai FAR dengan FRR skenario 1 dapat dilihat pada gambar 3. Nilai FAR terendah yaitu $20 \%$ pada kondisi terang dengan jarak $100 \mathrm{~cm}$. Nilai FRR 0\% pada kondisi terang dengan jarank 50 $\mathrm{cm}$. 
Hasil Uji Coba Skenario 2 dapat dilihat pada tabel 6.

Tabel 6. Hasil Uji Coba Skenario 2

\begin{tabular}{|c|c|c|c|c|}
\hline $\begin{array}{l}\text { kondisi } \\
\text { cahaya }\end{array}$ & $\begin{array}{l}\text { jarak } \\
(\mathrm{cm})\end{array}$ & $\begin{array}{l}\text { akurasi } \\
(\%)\end{array}$ & $\begin{array}{c}\text { FAR } \\
(\%)\end{array}$ & $\begin{array}{l}\text { FRR } \\
(\%)\end{array}$ \\
\hline Terang & 50 & 80 & 20 & 0 \\
\hline Terang & 100 & 20 & 20 & 60 \\
\hline Redup & 50 & 20 & 20 & 60 \\
\hline Redup & 100 & 0 & 20 & 80 \\
\hline
\end{tabular}

Akurasi tertinggi pada skenario 2 adalah $80 \%$ pada kondisi cahaya terang dan jarak $50 \mathrm{~cm}$. Akurasi terendah $0 \%$ pada kondisi redup dengan jarak 100 $\mathrm{cm}$. Perbandingan akurasi dapat dilihat pada gambar 4.

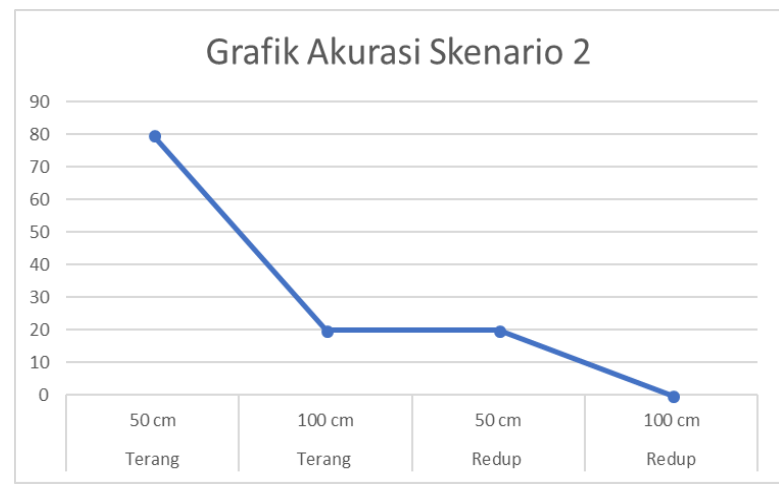

Gambar 4. Grafik Akurasi Skenario 2

Pada skenario 2 akurasi maksimal lebih baik dari pada skenario 1. Tren penurunan akurasi dari kondisi jarak dan cahaya hampir sama dengan skenario 1. Namun ada dua akurasi yang sama $20 \%$ pada kondisi yang berbeda, yaitu jarak $100 \mathrm{~cm}$ cahaya terang dan jarak $50 \mathrm{~cm}$ cahaya redup.

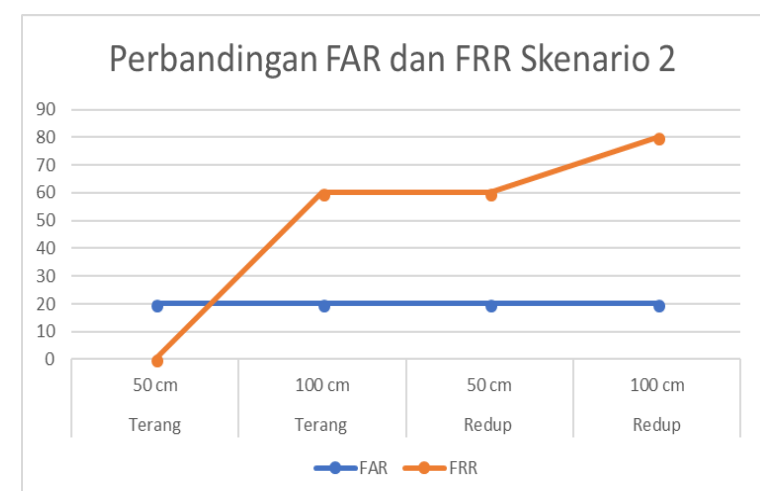

Gambar 5. Perbandingan FAR dan FRR Skenario 2

Nilai FAR pada semua kondisi skenario 2 bernilai sama yaitu 20\%. Nilai FRR 0\% pada kondisi terang dengan jarak $50 \mathrm{~cm}$. perbandingan nilai FAR dengan FRR skenario 2 dapat dilihat pada gambar 5 .

Hasil Uji Coba Skenario 3 dapat dilihat pada tabel 7
Tabel 7. Hasil Uji Coba Skenario 3

\begin{tabular}{|c|c|c|c|c|}
\hline $\begin{array}{l}\text { kondisi } \\
\text { cahaya }\end{array}$ & $\begin{array}{l}\text { jarak } \\
(\mathrm{cm})\end{array}$ & $\begin{array}{l}\text { akurasi } \\
(\%)\end{array}$ & $\begin{array}{l}\text { FAR } \\
(\%)\end{array}$ & $\begin{array}{l}\text { FRR } \\
(\%)\end{array}$ \\
\hline Terang & 50 & 80 & 20 & 0 \\
\hline Terang & 100 & 60 & 0 & 40 \\
\hline Redup & 50 & 20 & 20 & 60 \\
\hline Redup & 100 & 0 & 60 & 40 \\
\hline
\end{tabular}

Dari tabel 7 dapat diketahui bahwa akurasi tertinggi adalah $80 \%$ pada kondisi cahaya terang dan jarak $50 \mathrm{~cm}$. Perbandingan akurasi dapat dilihat pada gambar 6. Dari gambar tren akurasi turun hampir sama dengan dua skenario sebelumnya yaitu skenario 1 dan 2. Pada kondisi jarak $100 \mathrm{~cm}$ keadaan redup mempunyai akurasi 0\%, kondisi ini sama dengan skenario 1 dan 2. Dari hasil skenario 1 sampai 3 dapat diketahui bahwa pencahayaan berpengaruh sangat besar terhadap akurasi.

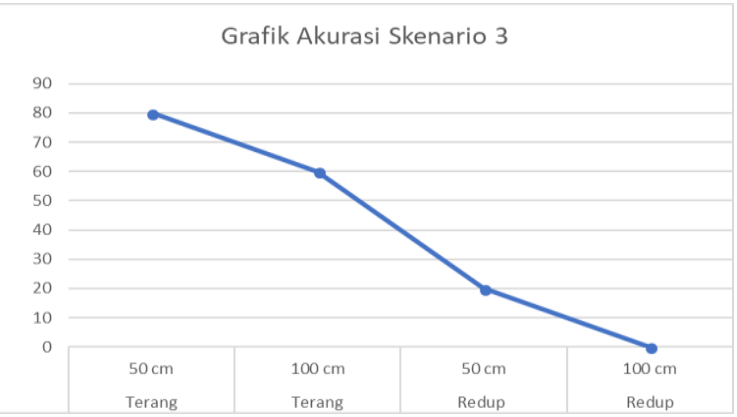

Gambar 6. Grafik Akurasi Skenario 3

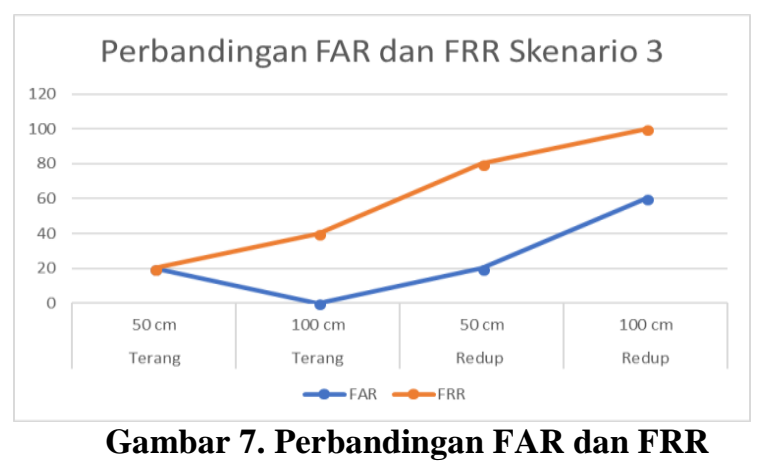
Skenario 3

Nilai FAR terendah yaitu 0\% pada kondisi terang dengan jarak $100 \mathrm{~cm}$. Nilai FRR 0\% pada kondisi terang dengan jarak $50 \mathrm{~cm}$. Perbandingan nilai FAR dengan FRR skenario 3 dapat dilihat pada gambar 7.

Hasil Uji Coba Skenario 3 dapat dilihat pada tabel 8

Tabel 8. Hasil Uji Coba Skenario 4

\begin{tabular}{|c|c|c|c|c|}
\hline $\begin{array}{l}\text { kondisi } \\
\text { cahaya }\end{array}$ & $\begin{array}{l}\text { jarak } \\
(\mathrm{cm})\end{array}$ & $\begin{array}{l}\text { akurasi } \\
(\%)\end{array}$ & $\begin{array}{l}\text { FAR } \\
(\%)\end{array}$ & $\begin{array}{l}\text { FRR } \\
(\%)\end{array}$ \\
\hline Terang & 50 & 80 & 20 & 0 \\
\hline Terang & 100 & 80 & 20 & 0 \\
\hline Redup & 50 & 60 & 20 & 20 \\
\hline Redup & 100 & 0 & 60 & 40 \\
\hline
\end{tabular}

Dari tabel 8 dapat diketahui bahwa akurasi tertinggi adalah $80 \%$ pada kondisi cahaya terang dan 
jarak $50 \mathrm{~cm}$. Akurasi terendah pada kondisi redup dengan jarak $100 \mathrm{~cm}$ yaitu 0\%. Perbandingan akurasi dapat dilihat pada gambar 8. Penurunan akurasi yang sangat drastis terjadi dari kondisi jarak $50 \mathrm{~cm}$ cahaya sedup ke kondisi jarak $100 \mathrm{~cm}$ cahaya redup yaitu dari $60 \%$ ke $0 \%$. Dari sekenario 1 sampai dengan 4 pada kondisi jarak $100 \mathrm{~cm}$ dengan cahaya redup akurasinya $0 \%$. Sedangkan pada kondisi jarak $50 \mathrm{~cm}$ cahaya terang dari skenario 1 sampai 4 ada tren naik.

Nilai FAR terendah yaitu $20 \%$ terjadi pada tiga kondisi terang dengan jarak 50 dan $100 \mathrm{~cm}$ dan kondisi redup dengan jarak $50 \mathrm{~cm}$. Nilai FRR $0 \%$ pada kondisi terang dengan jarak 50 dan $100 \mathrm{~cm}$. Perbandingan nilai FAR dengan FRR skenario 4 dapat dilihat pada gambar 9 .

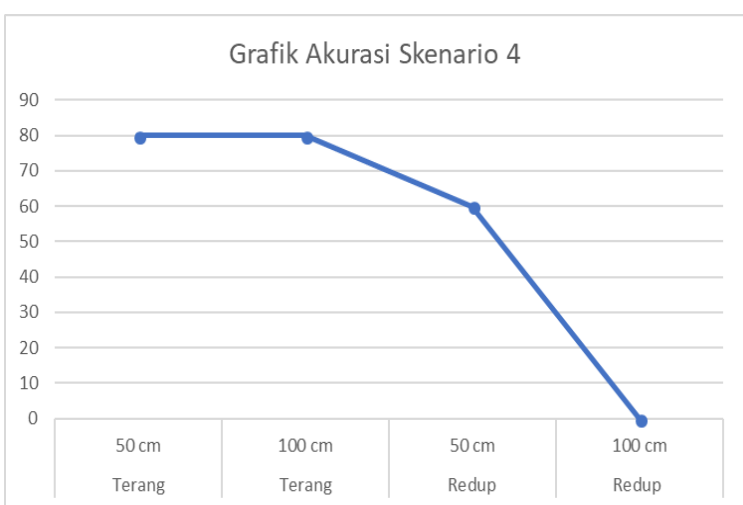

Gambar 8. Grafik Akurasi Skenario 4

\begin{tabular}{|c|c|c|c|}
\hline \multicolumn{4}{|c|}{ Grafik Perbandingan FAR FRR Skenario 4} \\
\hline \multicolumn{4}{|l|}{100} \\
\hline \multicolumn{4}{|l|}{80} \\
\hline \multicolumn{4}{|l|}{40} \\
\hline 0 & \multicolumn{3}{|c|}{20} \\
\hline $50 \mathrm{~cm}$ & $100 \mathrm{~cm}$ & $50 \mathrm{~cm}$ & $100 \mathrm{~cm}$ \\
\hline Terang & Terang & Redup & Redup \\
\hline \multicolumn{4}{|c|}{$\rightarrow F A R \rightarrow F R R$} \\
\hline \multicolumn{4}{|c|}{$\begin{array}{c}\text { Gambar 9. Perbandingan FAR dan FRR } \\
\text { Skenario } 4\end{array}$} \\
\hline \multicolumn{4}{|c|}{$\begin{array}{l}\text { Rata-rata akurasi dari empat skenario uji coba dapa } \\
\text { dilihat pada tabel } 9 .\end{array}$} \\
\hline \multicolumn{4}{|c|}{ Tabel 9. Rata-rata Hasil Uji Coba } \\
\hline Skenario & Akurasi (\%) & $F A R(\%)$ & $\begin{array}{l}\text { FRR } \\
(\%)\end{array}$ \\
\hline 1 & 30 & 45 & 25 \\
\hline 2 & 30 & 20 & 50 \\
\hline 3 & 40 & 25 & 35 \\
\hline 4 & 55 & 30 & 15 \\
\hline
\end{tabular}

Dari tabel 9 dapat diketahui bahwa rata-rata akurasi tertinggi adalah $55 \%$ yaitu pada skenario 4 .
Sedangkan rata-rata akurasi terendah adalah $30 \%$ pada skenario 1 dan 3 .

Untuk mempermudah analisa hasil skenario 1 sampai 4 dapat dilihat grafik pada gambar 10 dan 11. Perbandingan akurasi dapat dilihat pada gambar 10 sedangkan perbandingan FAR dan FRR pada gambar 11. Nilai FAR terendah yaitu $20 \%$ terjadi pada tiga kondisi terang dengan jarak 50 dan $100 \mathrm{~cm}$ dan kondisi redup dengan jarak $50 \mathrm{~cm}$. Nilai FRR $0 \%$ pada kondisi terang dengan jarak 50 dan $100 \mathrm{~cm}$.

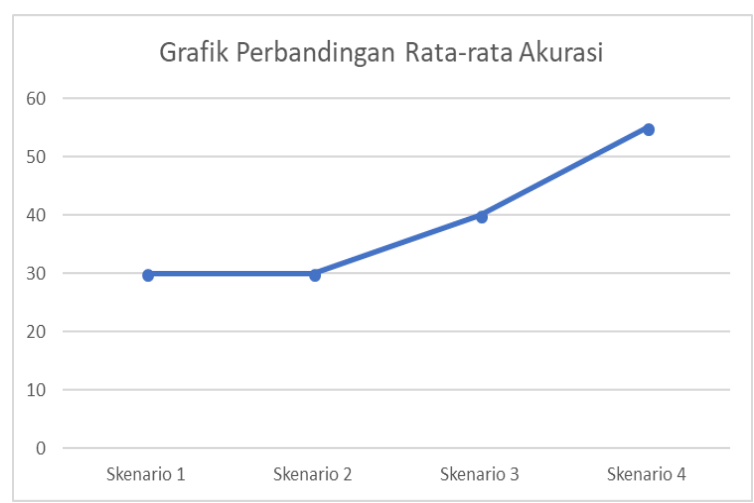

Gambar 10. Grafik Rata-rata Akurasi Skenario

Dari gambar 10 dapat dilihat bahwa dari skenario 1 sampai dengan 4 tren rata-rata akurasi meningkat. Paningkatan akurasi ini pengaruh dari jumlah data latih yang digunakan. Semakin banyak data latih yang digunakan maka semakin baik hasil akurasinya. Hal itu terjadi karena dengan banyaknya data latih yang digunakan maka sistem mempunyai data ciri dari suatu data citra wajah semakin detail.

Dari hasil skenario 1 sampai 4 akurasi tertingginya terjadi pada kondisi jarak $50 \mathrm{~cm}$ dengan cahaya terang. Sehingga kondisi yang ideal untuk mencapai akurasi yang maksimal yaitu pada jarak 50 $\mathrm{cm}$ dengan cahaya terang. Hal ini disebabkan karena dengan jarak $50 \mathrm{~cm}$ dengan kondisi terang data citra wajah dapat ditangkap dengan kualitas yang baik sehingga data citra memiliki ciri wajah yang detail. Dengan adanya ciri wajah yang detail maka sistem dapat mengenali citra wajah dengan baik.

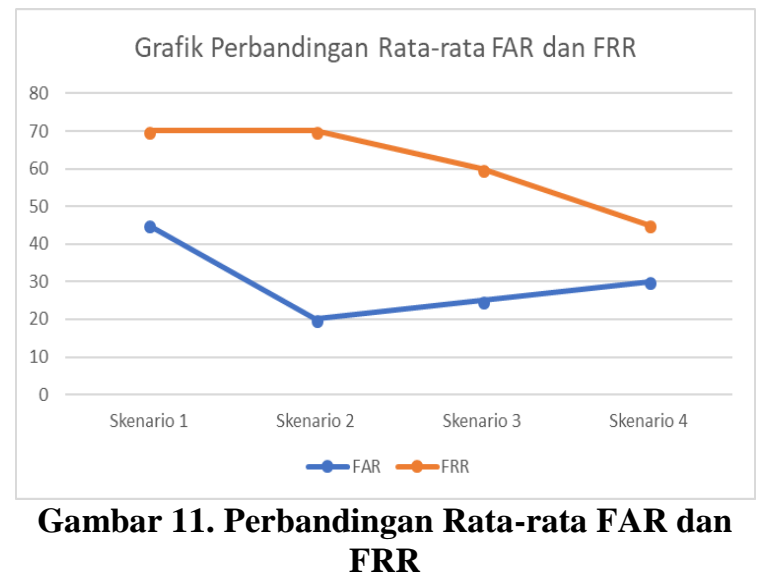

Dari gambar 11 tren nilai FAR dan FRR menurun, hal itu bearti penggunaan data latih yang banyak kualitas pengenalan wajah semakin baik. 
Namun ada perbedaan tren nilai FAR dan FR, jika nilai FRR dari skenario 1 sampai 4 trenya terus turun, maka nilai FAR dari skenari 1 ke dua turun dan setelah itu dari skenario 2 sampai 4 naik. Dari hasil ini untuk mendapatkan nilai FAR yang optimal data latih yang ideal digunakan adalah 2 .

\section{KESIMPULAN}

Dari analisa hasil uji coba yang telah dilakukan dapat disimpulkan sebagai berikut :

1. Akurasi pengenalan wajah dengan menggunakan metode ektrasi fitur eigenface dan K-NN mencapai $80 \%$.

2. Nilai rata-rata FAR terendah adalah $20 \%$ sedangkan FRR 15\%

3. Semakin banyak data latih yang digunakan akurasinya semakin tinggi.

4. Akurasi optimal didapat pada kondisi jarak $50 \mathrm{~cm}$ dengan cahaya terang.

\section{PUSTAKA}

Adiyat, Iqbal. 2013. Aplikasi Pengolahan Citra Digital Berbasis Flash pada Perangkat Mobile. Pontianak: Universitas Tanjungpura.

Ahmad, U. 2009. 10 langkah membuat program pengolahan citra menggunakan visual C\#. Yogyakarta: Graha Ilmu.

Efendy, Bobby. 2009. Autentifikasi Telapak Tangan pada Citra Digital Menggunakan Metode Support Vector Machine (SVM). Madura: Skripsi Universitas Trunojoyo

Fatta, H. A. 2009. Rekayasa Sistem Pengenalan Wajah. Yogyakarta: ANDI.

Fitriyah, N., dkk. 2015. Analisis dan Simulasi Sistem Pengenalan Wajah dengan Metode Fisherface Berbasis Outdoorvideo. Seminar Nasional Universitas PGRI Yogyakarta. 432438.

Fuad, N. 2017. Pemanfaatan K-Nearest Neighbor Pada Klasifikasi Image Berdasarkan Pola Fitur dan Tekstur. JUOTICLA, Vol. 2, No. 1.

Kurniawati A. T. dan A. R. Dwi Rama. 2015. Aplikasi Pengenalan Wajah Menggunakan Metode Eigenface dengan Bahasa Pemrograman Java. Seminar Nasional Sains dan Teknologi Terapan III. 315-326.

Pamungkas, D.P., Fajar, R.H. 2017. Implementasi Metode PCA dan Citu Block Distance Untuk Presensi Mahasiswa Berbasis Wajah. Malang: LPPM STIKI Malang

Pratiwi, D. E. dan Agus Harjoko. 2013. Implementasi Pengenalan Wajah Menggunakan PCA (Principal Component Analysis). IJEIS. 3. 175-181.

Putra, Darma, 2009. Sistem Biometrika Konsep Dasar, Teknik Analisis Citra, dan Tahapan membangun Aplikasi Sistem Biometrika. Yogyakarta: ANDI.

Putra, R. S. 2013. Perancangan Aplikasi Absensi dengan Deteksi Wajah Menggunakan Metode Eigenface. Pelita Informatika Budi Darma. 4. 130-137.
Salamun. 2016. Rancang Bangun Sistem Pengenalan Wajah Dengan Metode Principal Component Analysis. Jurnal Teknologi dan Sistem Informasi UNIVRAB VOL. 1 No. 2, Juli 2016, 1.

Sinwar, D., Kaushik, R. 2014. Study of Eucliean And Manhattan Distance matrics using Simple K-Means Clustering. International Journal For Research in Applied Science And Engineering Technology (IJRASET). Vol. 2, No. 5.

Wang, M. Y., Hideaki. T. 2017. Individual Recognition and the Face Inversion Effect in Medaka Fish (Oryzias Latipes). eLife Research Article. (https://search.proquest.com/444260dd05ba-4edf-a5b7-abcbd0129fd2, diakses 8 Juni 2018).

Wulanningrum, R. 2018. Penggunaan Algoritma KNearest Neighbor untuk Identifikasi Citra Kamboja. Generation Journal, Vol. 2, No.2. 2008. Kamus Besar Bahasa Indonesia Edisi Keempat. Jakarta: Gramedia Pustaka Utama 